\title{
DUUNARIJOUKKO VAILLA TURVAA
}

\author{
Pentti Peltoniemi \\ YTM, Helsingin yliopisto
}

"Älä sano olevasi freelancer!", opasti runsaan 14000 jäsenen Suomen Journalistiliiton (SJL) freelancer-asioihin perehtynyt lakimies vuonna 2016 liiton freelancer-jäseniä työttömyysturvalain muutoksesta. ${ }^{1}$ Lakimuutos oli johtanut siihen, että freelancereita alettiin luokitella työ- ja elinkeinotoimistoissa yrittäjiksi. SJL:n jäsenistä useampi kuin yksi kymmenestä oli tuolloin freelancer. Vain osa heistä halusi tulla luokitelluksi yrittäjäksi. ${ }^{2}$

Kuinka oli mahdollista, että vapaa toimittaja $^{3}$, kuvaaja tai graafikko ei voinut kertoa olevansa freelancer menettämättä oikeuttaan työttömyyspäivärahaan? Lakimies oli opastuksessaan oikeassa: parempi välttää katsetta kuin menettää sosiaaliturvasta maksettavaa tukea. Entä se kollektiivinen tuki, joukkovoima, oman ammattiyhdistyksen tuki, koko ammatillisen liikkeen tuki?

Työmarkkina-aseman muutosta kuvannut luottamushenkilö oli taustahaastattelussa ko- kemuksensa perusteella kriittinen. Kyseessä on "perustavaa laatua oleva etujen ristiriita. Työsuhteiset eivät seiso riittävästi yhteisessä rintamassa”. ${ }^{4}$

Tarkastelen tässä artikkelissa journalistista työtä tekevien freelancereiden työmarkkinaaseman ja ammattiyhdistystoiminnan muutoksia 1960-luvun puolivälistä 1980-luvun alkuun. Aikakaudella järjestäydyttiin, neuvoteltiin ja solmittiin ensimmäiset työehtosopimukset. Sitten oli takaiskujen aika. Lainsäädäntö, ennakkopäätökset ja etujärjestötulkinnat johtivat lopputulokseen, missä siinsivät 2000luvun alun pakkoyrittäjyys sekä pätkätöiden läpimurto. Lähdeaineistona käytän freelancejärjestöjen historiikkeja ja kokousaineistoja sekä vuoden 1975 freelancerlakkoa käsittelevää valtakunnansovittelijan toimiston aineistoa. Lisäksi hyödynnän viittä luottamushenkilöhaastattelua sekä kirjeenvaihtoa vuosilta 2015-2017.

1 ”Älä sano olevasi freelancer!," Journalisti, 1/2016, Journalistiliiton freelance-asioihin erikoistunut lakimies Jussi Salokangas.

2 Pirkko Leino-Kaukiainen ja Leena Riska-Campbell, Ei mikään yhden illan juttu. Journalistien järjestäytymisen vuosisata (Helsinki: Edita, 2018), 219-225.

3 "Lehtimies" ja "toimittaja" käsitetään synonyymeiksi. ”Journalisti" viittaa niitä laajemmin journalistista työtä tekeviin.

4 Maria Markus, haastattelu tekijän kanssa 8.12.2015.

5 Haastattelut tekijän kanssa: Seppo Metso, 29.10.2015; Maria Markus, 8.12.2015; Ingrid Svanfeldt, 12.4.2016; Kari Varvikko, 12.5.2016; Jukka Väyrynen, 15.9.2015; Sähköpostikirjeet tekijälle: Telle Virtanen, 15.9.2020 ja 16.9.2020 sekä Jorma Hyvönen 15.9.2020; Airi Leppänen \& Pirjo Munck, toim., RTTL 1961-2011: 50 vuotta (Helsinki: Edita, 2011); Kauko Ainasoja et al., toim., Vuosisata sitoutunutta journalismia 1907-2007: Suomen Sosialidemokraattinen Sanomalehtimiesliitto SSSL ry (Turenki: SSSL ry, 2007); Kyösti Suonoja, Suomen Kirjatyöntekijäin Liiton historia, vol. 2, Suomen Kirjatyöntekijäin liiton sopimuspolitiikka, ammattiyhdistystoiminta ja suhteet muihin organisaatioihin 1915-1973 (Jyväskylä: SKL-FBF ry, 1977); Taimi Torvinen, Herraskaisklubista ammattiyhdistystoimintaan, teoksessa HSY-HJF 60: Helsingin Sanomalehtimiesyhdistys - Helsingfors Journalist Förening 1920-1980 (Helsinki: HSY, 1980); Erkki Wiksten, "SSSL:n seitsemäs kymmenvuotistaival," teoksessa Sanan vapaus, toim. Jyrki Pietilä et al. (Tampere: SSSL, 1978); Pirjo Munck, "Valistajista ammattimiehiksi: Toimittajien ammattilaistumisen pitkä tie 1771-1921" (Väitöskirja, Helsingin yliopisto, 2016), http://urn.fi/URN:ISBN:978-951-51-1983-4. 


\section{Sanomalehtimiesten ammatillinen järjestäytyminen}

Sanomalehtimiesten organisoituminen "herraskaisklubeista" ammattiyhdistystoiminnan alkioiksi alkoi 1800- ja 1900-lukujen vaihteessa. Ensimmäiset järjestöluonteisiksi perustetut "poliittiset lehtimiesyhdistykset" liittyivät vuoden 1905 suurlakon jälkeiseen eduskuntauudistukseen, joka johti nykymallisen puoluekentän ja sen tarpeita palvelevan lehdistön perustamiseen. Äänenkannattajien palveluksessa olleet lehtimiehet perustivat omia yhdistyksiään. ${ }^{6}$ Oikealle laidalle perustettiin Suomalainen Sanomalehtimiesliitto vuonna 1905, keskemmälle Nuorsuomalainen Sanomalehtimiesyhdistys vuotta myöhemmin ja ruotsinkielisen toimittajakunnan järjestöksi Finlands Svenska Publicistförbund vuonna 1907. Näiden porvarillisten järjestöjen yhteiselimeksi perustettiin Suomen sanomalehtimiesjärjestöjen keskusvaltuuskunta vuonna 1911 . $^{7}$

Vuonna 1907 perustettu Suomen Sosialidemokraattinen Sanomalehtiliitto (SSSL) liittyi heti samana vuonna perustettuun Suomen Ammattijärjestöön. Pirjo Munck arvioi, että porvaripuolen lehtimiesten omaseuraisuuteen saattoi vaikuttaa se, että sos.dem. lehdissä työskentelevät "lehtimiehet olivat jo neuvotelleet työnantajapuolen kanssa palkkatariffit kaikille työväenlehtien toimittajille" pian SSSL:n perustamisen jälkeen, vuonna $1908 .^{8}$

Poliittinen neliapila täydentyi, kun Maalaisliiton lehdistössä työskennelleet organisoituivat vuonna 1919 omaan etujärjestöönsä, Maalaisliiton Sanomalehtimiesyhdistykseen. ${ }^{9}$ Kansandemokraatit perustivat oman lehtikenttänsä toimittajajärjestöksi Yleisen Lehtimiesliiton (YLL) vuonna 1947. Sos.dem. puolueen ja SAK:n hajoamisen myötä syntyi "skogilaisten” etujärjestöksi Toimittajaliitto vuonna 1959, joka liittyi YLL:n tavoin SAK:hon. SSSL puolestaan jätti tuolloin SAK:n ja vaihtoi "kääpiökeskusjärjestöön", uuteen SAJ:hin. ${ }^{10}$

Nykyisin poliittiset sanomalehtimiesyhdistykset hoitavat pääosin jäsentensä sosiaalisen, aatteellisen ja koulutuksellisen tarpeen. Varsinainen edunvalvonta on keskittynyt vuonna 1921 perustettuun Sanomalehtimiesten Liittoon (SSL), jonka nimi on ollut vuodesta 1993 lähtien Suomen Journalistiliitto (SJL). Munckin mukaan merkittävin syy valtakunnallisen ammattiliiton perustamiselle oli palkkojen ostovoiman romahtaminen sisällissodan jälkeen. Mallia palkkatason parantamiseen saatiin Suomen Kirjatyöntekijäin Liitolta, joka vuonna 1919 onnistui neuvottelemaan jäsenilleen kalliin ajan korotuksen - palkkoja nostettiin vuoden lopulla $245-290$ prosenttia. ${ }^{11}$

Työnantajien järjestäytyminen noudatti pitkälti samaa kaavaa. Vuonna 1900 perustettiin kirjapainonomistajain Suomen Kirjanpainajayhdistys, jota seurasi kuutta vuotta myöhemmin Suomen Graafillisen Teollisuuden Harjoittajain Liitto ja vihdoin vuonna 1993 Graafisen Teollisuuden Työnantajaliitto. Sittemmin syntyi fuusioiden myötä Viestinnän Keskusliitto vuonna 2002 sekä vuonna 2017 Medialiitto.

Kustantajat puolestaan perustivat vuonna 1910 Suomen Lehdenjulkaisijat, Finlands Tidningsutgivare -yhtymän, josta muotoutui kuutta vuotta myöhemmin Suomen Sanomalehdenkustantajain Liitto, Finlands Tidningsförläggareförbund. Suureen yhteislevikkiin ja laajaan poliittiseen kannatukseen pohjanneen työväenlehdistön merkittävimmäksi etujärjes-

6 Torvinen, Herraskaisklubista, 12-13.

7 Munck, Valistajista, 179-180.

8 Munck, Valistajista, 180-182.

9 Torvinen, Herraskaisklubista, 12.

10 Torvinen, Herrasklubista, 12-13; Tapio Bergholm, Sopimusyhteiskunnan synty, vol. 2, Hajaannuksesta tulopolitiikkaan: SAK 1956-1969 (Keuruu: Otava, 2007), 98-99; ks. myös Wiksten, SSSL:n seitsemäs, 14-15.

11 Leino-Kaukiainen ja Riska-Campbell, Ei mikään, 26-29; Munck, Valistajista, 201; 56-60. 
töksi kehittyi Työväen Kustannusliikkeiden Liitto, joka perustettiin vuonna 1917.

Lehtimiesten keskuudessa muodostivat poikkeuksen työväenlehtien toimittajat, joiden ammattijärjestö SSSL onnistui laajentamaan palkkatariffisopimuksensa työehtosopimukseksi lokakuussa 1936. ${ }^{12}$ Palkka- ja muut työehdot olivat talokohtaisia: tariffeja, henkilökohtaisia palkkoja, joillakin eläkeoikeus. SSL ylsi samaan vasta vuonna $1967 .{ }^{13}$

Silti jo keväällä 1956 graafisen alan työnantaja- ja työntekijäjärjestöt olivat neuvotelleet Arbetarbladetin pitkäaikaisen päätoimittajan, pääministeri K.-A. Fagerholmin ehdottomasta työrauhavelvoitteesta. Hanke kaatui, koska työnantajajärjestöissä pelättiin, että se avaa tien "toimittajien työehtosopimuksiin. Niitä työnantajat olivat vastustaneet johdonmukaisesti”. ${ }^{14}$

Järjestö- ja sopimustoiminnan ulkopuolelle jäivät sekä lehdistön että Yleisradion freelancerit. Työmarkkinatasolla journalistikunnan järjestäytyminen oli 1960-luvulle tultaessa hajallaan: SSL kuului TVK:hon, kaksi vasemmistolaista liittoa SAK:hon ja yksi SAJ:hin. Myös SSL:ssä oli useita kertoja esitetty liittymistä SAK:hon: jo perustamisvaiheessa, 1930-luvulla, 1941, jatkosodan jälkeen, 1950-luvulla, 1960-luvun puolivälissä ja vielä 1970-alussa. Keskusjärjestökysymys on mielenkiintoinen elementti tarkasteltaessa freelancereiden järjestäytymistä sekä heidän ammattiyhdistystoimintansa saavutuksia hieman edempänä. ${ }^{15}$

\section{Yleisradion suljettu saareke}

Yleisradion toimittajat järjestäytyivät ammatillisesti 35-50 vuotta printtikollegoitaan myöhemmin. Toki oli media itsekin graafista alaa nuorempi. Yleisradion ensimmäiset herraklubit aloittivat 1930-luvun puolivälissä. Yksi niistä oli vuonna 1936 perustettu Suomen Radioselostajat, Finlands Radioreportrar (SRS). Lähemmäksi työmarkkinatoimintaa päästiin Hella Wuolijoen pääjohtajakaudella. Vuonna 1947 perustettiin Yleisradion Henkilökunnan Ammattiyhdistys (YHA). Kun yhdistys liittyi 1950-luvun alussa teollisuusliittoperiaatteella toimivaan SAK:laiseen Liiketyöntekijäin Liittoon, eivät toimittajat katsoneet kuuluvansa joukkoon. ${ }^{16}$

Oman yhdistyksen puutetta eivät myöskään korvanneet vuonna 1950 perustettu Yleisradion ammattiyhdistysten yhteistyövaliokunta ja vuosikymmenen puolivälissä perustettu Yleisradion virkailijat -yhdistys. Toimittajien oma ammattiyhdistystoiminta alkoi toden teolla vasta 1960-luvun alussa, kun Radio- ja televisiotoimittajat - Radio och television redaktörerna r.y. (RTTY, myöh. RTTL) perustettiin. RTTL teki ensimmäisen työehtosopimuksensa 29.4.1964. ${ }^{17}$

Ajatus muodostaa jonkinlainen yhteistyöelin joko SSL:n tai vuonna 1949 aloittaneen Suomen Aikakauslehdentoimittajien liiton (SAL:n) kanssa ei toteutunut. Yksikään keskusjärjestö ei tullut kyseeseen. ${ }^{18}$ Mainos-TV:n ohjelmatyöntekijät järjestäytyivät vuonna 1966

12 Suonoja, Suomen Kirjatyöntekijäin, 62-63; Torvinen Herrasklubista, 12-13.

13 Torvinen, Herrasklubista, 38; Leino-Kaukiainen ja Riska-Campbell, Ei mikään, 163. Torvisen allekirjoitus pvm. 4.4.1967, Leino-Kaukiaisen 6.4.1967.

14 Markku Mansner, Suomalaista yhteiskuntaa rakentamassa: Suomen Työnantajain Keskusliitto 1956-1982 (Jyväskylä: Teollisuuden Kustannus Oy, 1990), 146-148.

15 Leino-Kaukiainen ja Riska-Campbell, Ei mikään, 49-50, 147, 152-153, 211-213; Torvinen, Herrasklubista, 46-47. Torvisen mukaan HSY:n toimittaja Toivo Vitikka esitti vuonna 1941 "vastavetona" harkittavaksi liittymistä” SAK:hon SDP:n suositeltua jäsenilleen suojeluskuntia.

16 Leppänen \& Munck, RTTL 1961-2011, 9-10. Sosiaalisesta samaistumisesta, ks. Leino-Kaukiainen ja RiskaCampbell, Ei mikään, 14, 22-24.

17 Leppänen \& Munck, RTTL 1961-2011, 10.

18 Ibid. 
omaan, Akavaan liittyneeseen Mainos-TV:n ohjaajat ja toimittajat -yhdistykseensä, kunnes vuonna 1972 he vaihtoivat RTTL:ään. ${ }^{19}$

Freealancerien osuus koko toimittajakunnasta oli vajaat 10 prosenttia, eikä SSL:sta, SAL:sta ja RTTL:sta ollut heidän etujensa ajajiksi. Ammattiyhdistykset etsivät edelleen toimintamuotojaan.

Ensimmäisenä freelancereiden asemaa lähtivät parantamaan Yleisradiolle työskennelleet kokeneet freelancetoimittajat. Viisi "vanhaa" ja 48 "nuorta" toimittajaa kokoontui 16.5.1968 Vanhan kellarin Karhu-kabinettiin. Perusteilla oli radion ja TV:n freelancer-yhdistys. Mukaan tulisi "vain tunnetusti ammattitaitoisia free lance-toimittajia radion, tv: $n$ ja Mainos-tv:n piiristä". ${ }^{20}$ Radioselostajista poiketen ajatus oli korostaa enemmän edunvalvontaa kuin sosiaalista yhdessäoloa. Uuden yhdistyksen tärkeät määreet olivat ammattitaito ja ammattiyhdistys.

Ammattiyhdistystä olivat valmistelleet "vanhat", muun muassa Paavo Einiö, Jaakko Jahnukainen, Seppo Jylhä ja Kauko Saarentaus. Nuorten joukossa oli sekä toimittajia, näyttelijöitä että opiskelijoita. Mukana oli henkilöitä, jotka suuntautuivat muutamassa vuodessa esimerkiksi tiedotustutkimukseen, elokuvasektorille ja muihin viestinnän töihin. ${ }^{21}$

Perustava kokous järjestettiin 5.6.1969 Insinööritalon kerhohuoneessa. Nimeksi tuli Radio ja tv-free lancerit ry - Radio och tvfree lancers rf (RTFL). Selostajaklubin rinnalla RTFL oli tuore ja vahva kilpailija. Haastettu reagoi. Ensi töiksi klubin nimeen lisättiin maagiset kaksi kirjainta, "T” ja "V”. Nimeksi tuli Suomen Radio- ja TV-selostajat - Finlands
Radio- och TV-reportrar (SRTVS). ${ }^{22}$ Ärhäkät "herraklubilaiset" purkivat närkästystään radikaalista tulokkaasta. Esimerkiksi Markus Similä kritisoi Helsingin Sanomissa lokakuussa 1971 yhdistyksen puheenjohtajana toimineen Tuula Sarrolan lausuntoja:

Ammattimaisena freelancerina en tietenkään halua olla vastustamassa etujemme parantamista, päinvastoin. Kysymys onkin menettelytavoista, julkisesta käyttäytymisestä, josta varjo nyt aiheettakin lankeaa jokaiseen Yleisradion avustajaan. Julkisen kritiikin paineessa työskentelemiseen tottuneille tämä seikka ei ole suinkaan merkityksetön. ${ }^{23}$

Toinen huolestunut oli RTTL:n puheenjohtajana vuosina 1974-1975 toiminut Arne Wessberg, joka kertoi RTTL-historiikissa:

Kyllähän talossa oli aika voimakas stalinistinen ydin, toveripiiri, joka omine julkaisuineen koetti monin tavoin vaikuttaa myös liiton sisällä. Se ei suinkaan aina tapahtunut avoimen poliittisesti [...]. Mutta kyllä se oli taistolaisten kovaa aikaa. ${ }^{24}$

Laajat tulopoliittiset ratkaisut sekä yhteiskunnallinen progressiivisuus näkyivät freelancer-osastojen toiminnassa. Myös SRTVS alkoi nuorentua ja muuttua "klubista" ammattiyhdistykseksi. Puolestaan SSL:n vuonna 1967 solmimalla TES:lla oli käänteentekevä merkitys: sanomalehdissä perustettiin toimitusosastoja, minkä vuoden 1971 sääntömuutos mahdollisti, ja koska freelancerit eivät kuuluneet työpaikkaosastoihin, heille tuli tarve perustaa oma osasto.

Anne Kähkönen on kuvannut sitä, miten lehdistön freelancerit järjestäytyivät SAL:n suo-

19 Riska-Campbell, Sanomalehtimiehistä kasvoi, 412; Leppänen \& Munck, RTTL 1961-2011,129.

20 Valmistelukokouksen ptk., 16.5.1968, FOT C:1, Työväen Arkisto (TA), Helsinki.

21 Ibid.; ks. myös Erkki Tuomioja, Kukkaisvallasta Kekkosvaltaan (Jyväskylä: Tammi, 1993), 25.

22 Perustavan kokouksen ptk., 5.6.1968, FOT C:1, TA.

23 Markus Similä, "Vapaa toimittaja, piiloporvari: Kaikki emme ole vasemmistolaisia," Helsingin Sanomat,

Mielipidekirjoitus, 17.10.1971.

24 Leppänen \& Munck, RTTL 1961-2011, 18-19. 
jiin omaksi yhdistyksekseen vuonna $1972 .{ }^{25}$ Osaston perustaminen tapahtui TVK-talon juhlasalissa 8.6.1972 - SSL oli vielä tuolloin TVK:n jäsen. Lehdistön freelancerit aloittivat heti osastonsa perustamisen jälkeen määrätietoisen toiminnan. Tavoite oli selkeä: ansioiden kohentaminen, horisontissa vakituisten ansiotaso. Parannettavia asioita olivat palkkiot, sosiaaliturva ja kirjanpito. Verottajan vaihteleva, jopa ristiriitainen suhtautuminen oli oikaistava. Jäsenyyden edellytyksenä oli, että noin 75 prosenttia tuloista kertyy "alan töistä”. Tästä tasosta voitiin joustaa, mikäli ansiot jäivät alhaisiksi työtilaisuuksien vähäisyyden tai sairauden vuoksi. Jäsenyyttä hakeneella ei saanut olla vakinaista kuukausipalkkaista työsuhdetta. Jäseneksi hyväksyttiin toimittajat, kuvaajat, kustannustoimittajat ja käsikirjoittajat. Ansiot saattoivat koostua sekä painetun että sähköisen median töistä.

Järjestäytyneet freelancerit olivat ylpeitä ammatistaan. Mukaan ei haluttu pr- ja mainostekstien tekijöitä. Freelancetoimittajat sijoitettiin kuuteen kategoriaan, joista esim. todellisella freelancerilla oli "avustussuhteita useampiin, usein myös eri kustantajien lehtiin. Käytännössä 2-5 pääasiallista työnantajaa. Ei mitään sosiaalisia etuja”. Työt olivat ennalta sovittuja, yleisesti tilaustöitä. ${ }^{26}$

\section{Ensimmäiset freelancer-sopimukset}

Vuodesta 1972 freelancetoimittajilla oli kolme omaa ammattiyhdistystä, SRTVS, RTFL sekä lehdistön FLO (SSL:n freelance-osasto). FLO-lyhenne ei juurtunut. Vuonna 2005 FLO:n työtä jatkamaan muodostettiin Suomen freelance-journalistit ry (SFJ).
RTFL pyrki omaan TES:een Yleisradion kanssa ja onnistui. Sopimus allekirjoitettiin 13.6.1974. Työnantajan puolesta työehtoneuvottelut hoiti keskusjärjestö STK:n jäsenliitto, Suomen Työnantajain Yleinen Ryhmä.

Sopimusta oli edeltänyt lakkovaroitus. Tapahtumakulku nosti esille "liittorajakysymyksen”. Vaikka RTTL ei hyväksynyt määräaikaisia edes jäsenikseen, lakkouhan edessä vakinaisten hallitus päätti 3.5.1974 äänin 8-2, ettei lakko koskisi kesätoimittajia eikä työehtosopimuksensa mukaisen määräaikaisen sopimuksen tehneitä. Näin RTTL antoi mahdollisuuden rikkurityövoiman käytölle. ${ }^{27}$ Lakko ei alkanut, joten rikkureita ei tarvittu.

Lakkouhalla saatu sopimus oli merkittävä, sillä siitä alkoi Yleisradion ja SAK:laisten freelancetoimittajien työehtosopimusyhteistyö, mihin liittyi myös SRTVS. Oli saatu läpimurto.

SAK:n eheytyksen yhteydessä oli perustettu uusi kokoomaliitto, Teknisten- ja Erikoisammattien liitto Tekeri. Neuvotteluvoimaansa parantaakseen RTFL liittyi Tekerin jäseneksi vuonna 1971, mitä RTFL korosti jäsenhankinnassaan, muun muassa lähestyessään ulkomailla toimivia radio- ja TV-uutisten freelancer-kirjeenvaihtajia. Tavoitteena oli saada kaikki 10 SAK:laista ammattiryhmää neuvotelluksi "periaatteessa samanmuotoisen työehtosopimuksen piiriin". ${ }^{28}$ Sääntönsä uudistanut SRTVS huolehti omiensa sopimusasioista liittymättä keskusjärjestöihin.

Lehtipuolella SAL liittyi SSL:n jäseneksi vuonna 1971. Lehtimarkkinat olivat kohtalaisen lyhyessä ajassa mullistuneet. Iso tekijä oli valoladonnan, offsetin ja muun uuden teknii-

25 Anna Kähkönen, ”Ei väkisin vaan väsyttämällä," teoksessa Lehdistön freet 30 vuotta 1972-2002, toim. Tuula Stenberg (Loimaa: Suomen Journalistiliiton Freelancer-osasto ry, 2002),19-20.

26 Kähkönen, Ei väkisin, 44-46; Perustavan kokouksen ptk. 8.6.1972, SSL:n Freelancer-osaston (FLO) arkisto, Suomen freelance-journalistit ry (SFJ), Helsinki; Kevätkokouksen ptk. 24.5.1973 (liitteet 1-4), SSL:n Freelancer-osaston (FLO) arkisto, Suomen freelance-journalistit ry (SFJ), Helsinki.

27 Hallituksen kokouksen pöytäkirja 3.5.1974, RTTL Järjestötoiminta 1.2.1. Radio- ja televisiotoimittajien liitto - Radio- och televisionsredaktörernas förbund r.y., RTTL:n arkisto, Helsinki.

28 Kari Lempisen ja Veikko Lappalaisen päiväämätön Terve ystävä -kirje syyskesällä 1974, FOT F:16 Kirjeenvaihtoa 1968-1991, TA. 
kan nopea kehittyminen. ${ }^{29}$ Lehtien ulkoasut mullistuivat, ja vuositilauksista siirryttiin entistä enemmän irtonumeromyyntiin. 1980-luvulle tultaessa iltapäivälehdet ottivat kasvavan osan irtonumeromyynnistä.

Perinteisten perhelehtien levikit saavuttivat huippunsa ja alkoivat hiipua. Sekä vanhat että uudet lehdet vaihtoivat omistajia. Merkittävin kauppa oli Lehtimiehet-konsernin siirtyminen vuonna 1988 Yhtyneet kuvalehdet -konsernin omistukseen. Murros oli alkanut jo 1970-luvulla. Ullamaija Kivikurun mukaan toimittaja oli tällöin illalla nukkumaan mennessään työssä yhden kustantajan lehdessä ja aamulla herätessään toisen. ${ }^{30}$

Lehtipuolen FLO neuvotteli oman sopimuksensa, kun "suositus freelance-tehtäviin liittyvistä kysymyksistä astui voimaan 1.4. 1975" SSL:n ja työnantajien GTT:n kesken. Sopimukseen oli tarkoitus liittää myös suositukset minimipalkkioista, mutta hanke jäädytettiin jäsenäänestyksen jälkeen. Osapuolet päättivät hankkia tarkemmat luvut freelancereiden ansiotasoista sekä ammatinharjoittamiseen liittyvistä kuluista. ${ }^{31}$

Kähkösen mukaan pyrkimykset saada freelancereiden asema kirjatuksi GTT:n ja SSL:n työehtosopimukseen omaksi freelancer-liitteeksi kaatuivat, kun GTT paalutti näkemyksekseen, että freelancer-suhde oli kauppa- eikä työsuhde. Vuonna 1979 korvikkeeksi tuli liittotasolla neuvoteltu "yhteinen avustajasopimuksissa käytettävä kaavake” sekä toimitusehdot. SSL postitti "kaavakkeen" sekä jäsentiedustelujen tuloksena laaditut palkkiosuositukset FLO:n jäsenille. Niiden takana ei ollut
GTT, minkä työnantajaliitto toi selvästi esille. ${ }^{32}$

Sopimuskentällä alkoi tapahtua, kun sähköisellä puolella työskentelevät freelancerit löysivät toisensa vuonna 1974. Syksyn 1974 aikana neuvoteltiin RTFL:n ja Radio- ja tvselostajien SRTVS:n fuusio allekirjoitusta vaille valmiiksi. Mutta fuusioyritys kariutui kalkkiviivoilla. Vaikuttaa siltä, että yhtenäisen ammattiosaston kaatoivat RTFL:n vaatimukset uuden järjestön hallintopaikkojen jaosta. RTFL vaati, että se saa hallituksesta puheenjohtajan paikan sekä kahdeksan jäsenpaikkaa ja SRTVS neljä jäsenpaikkaa. Neljä paikkaa ei riittänyt, ja lakkautuskokouksessaan marraskuussa 1974 SRTVS päätti vastoin neuvotteluissa sovittua olla lakkauttamatta itseänsä. ${ }^{33}$

Myös keskusjärjestökysymys vaikutti. RTFL kuului SAK:hon, ja SRTVS oli villi vakinaisten järjestön RTTL:n tavoin. Wessbergin johtaman yhdistyksen silmissä RTFL tuli sitä hankalammaksi tapaukseksi, mitä vahvemmaksi freelancereiden neuvotteluvoima kasvoi. Lakkovuoden 1975 alkaessa RTTL:n jäsenmäärä oli noin 600, RTFL:n noin 500 ja selostajien SRTVS:n toistasataa. ${ }^{34}$ RTTL edusti siten vähemmistöä kaikista Yleisradiossa työskentelevistä journalisteista. Ilmiselvästi liitossa pelättiin, että freelancerit saavat oman työehtosopimuksensa. Siinä tilanteessa RTTL:n olisi ollut vaikea pitää yllä entistä asemaansa. ${ }^{35}$

Sen lisäksi, että fuusion kaatumiseen vaikutti kysymys hallituspaikoista, siihen vaikuttivat politiikka, sopimusrajat sekä pelko osaavasta freelance-yhdistyksestä. Vaikeinta ajatus

29 Markku Rautonen, Apu: Sanan voimalla 1933-83 (Helsinki: A-lehdet Oy, 1983), 67, 130-133.

30 Kähkönen, Ei väkisin, 21.

31 FLO toimintakertomus 1975; Kähkönen, Ei väkisin, 27, 31-33.

32 Kähkönen, Ei väkisin, 27, 31-33.

33 Hallituksen ptk:t 7.10.1974, 1.11.1974, 12.11.1974, 26.11.1974, 3.12.1974 ja 13.12.1974; RTTL:n operaatio, ptk:t 7.10.1974 ja 12.11.1974, FOT C 1 Pöytäkirjat, TA.

34 Kalervo Kannisen lakkokokouspuhe, 30.6.1975, FOT H:13 Lakkoaineisto, TA.

35 Hallituksen ptk. 12.12.1974, 4 \$, RTTL:n arkisto 1.2.1.; Muistio toukokuu 1975, Valtakunnansovittelijan toimisto, käsiarkisto. 
fuusiosta oli ei-vakinaiset journalistit diskanneelle RTTL:lle. Rikkoakseen freelance-osastojen yhteistyörakennelman liitto suunnitteli kilpailevaa freelancer-jaostoa syksyllä 1974. RTTL:n hallitus totesi kuitenkin pian, että se "pitää ilahduttavana freelancejärjestöjen yhdistymiseen johtavaa kehitystä" ja että "tässä tilanteessa ei ole syytä harkita oman freelancerjaoston perustamista" ${ }^{36}$

\section{Vuosi 1975: lakko ja rikkurit}

Lehtipuolen freelancereiden ay-toiminta oli selvästi tasaisempaa. Jäsenkehitys kuvaa muutosta: 1980-luvun alkuun mennessä FLO:n jäsenmäärä oli noussut noin 150:een. Sähköisellä puolella jäseniä oli noin 600 , joista valtaosa kuului Freelance-ohjelmatyöntekijöihin eli FOT:iin. (RTFL:n nimi oli muuttunut vuodenvaihteessa 1975 FOT:ksi.) ${ }^{37}$ Kaikkiaan ammattimaisia freelancetoimittajia oli koko maassa runsaat tuhat. Myötätuulta oli, jäsenistön määrä kasvoi. Yleisradiossa edellisenä vuonna oman sopimuksensa tehneet freelancerit valmistautuivat huolella ja yhdessä kevään 1975 sopimusneuvotteluihin. Niissä ei edetty. RTTL "murehti yksinoikeudestaan" edustaa yksin Yleisradion journalistista henkilökuntaa.

FOT ja SRTVS antoivat lakkovaroituksen 13.5.1975. Valtakunnansovittelijan toimiston muistion mukaan lakkouhkaa purkavissa neuvottelussa RTTL:n puheenjohtaja "Wessberg lausui, että sopimukset, jotka on tehty kolmeksi kuukaudeksi tai pitemmäksi ajaksi kuuluvat RTTL:n sopimuksen piiriin [...]. Jos siis on kolme kuukautta tai sitä pitempi sopimus, noudatetaan RTTL:n sopimusta jäsenyydestä riippumatta”. ${ }^{38}$ Tähän FOT:n puheenjohtaja Börje J. Mattsson huomautti, että freelancer-asioiden kuulumiselle FOT:n sopimuksen piiriin ei ollut laillista estettä. Sovittelijan toimistossa "merkattiin, että Wessberg poistui neuvottelutilaisuudesta".

RTTL yritti selvittää, olivatko lakon alkaessa työhön tulevat rikkureita vai eivät. Hallituksen työvaliokunta muotoili lakon varalle nelikohtaisen suhtautumis- ja toimenpidepäätösesityksen: "RTTL ei tue lakkoa siltä osin, kuin freelancerjärjestöjen vaatimukset ulottuvat RTTL:n tes:n 2 \$:n alueelle, joka tarkoittaa 3 kk tai sitä pitempiä työsopimuksia."

Proseduuri oli toisinto edelliskeväältä. Tuolloin liitto oli lakkouhan edessä äänin 8-2, yhden jäsenen pidättäytyessä äänestyksestä, hylännyt ehdotuksen, jossa muun muassa esitettiin, että "RTTL:n jäsenten tulee noudattaa lakossa olevien yhdistysten määrittelemiä lakkorajoja”. Nyt, vuotta myöhemmin, Christian Sundgren esitti Airi Valkaman kannattamana hallituksen kannaksi, että RTTL:n tuli tukea toimittajakollegoita lakkorajojen määrittämissä puitteissa. Sundgrenin esitys kaatui äänin 7-2. Päätökseen jätettiin eriävä mielipide: "Hallituksen enemmistön tekemä päätös on työnantajamielinen mutta ei tuki oikeuksiensa puolesta taitelevalle veljesjärjestölle”. Väite, että RTTL myötäili työnantajan kantaa, joka oli "uusien apulaisjohtajanimitysten myötä" muuttunut, perustui tietoon: yhtiö oli jo kertaalleen ottanut kannan, jonka mukaan määräaikaissopimukset kuuluivat FOT:n sopimuksen piiriin. Viittaus apulaisjohtajiin oli piikki: toinen uusista johtajista oli Veikko Helteen työministeriaikainen avustaja Ilmo J. Kolamo (sittemmin von Bell), joka oli juuri siirtynyt Yleisradioon VN:n kanslian tulopoliittista neuvottelevaa virkamiestä avustavan lakimiehen tehtävistä. ${ }^{39}$

36 Leppänen \& Munck, RTTL 1961-2011, 42; hallituksen ptk:t 4.11.1974 ja 12.12.1974, RTTL:n arkisto 1.2.1.; Aiemmin ko. henkilö oli haikaillut SAK-jäsenyyttä, RTFL:n vk:n 8.12.1969 ptk., FOT C:1, TA. 37 Freelance-ohjelmatyöntekijät FOT hyväksyttiin 13.12.1974, kirjattiin yhdistysrekisteriin vuonna 1990. 38 Hallituksen ptk. 24.5.1974, RTTL:n arkisto 1.2.1. 
Valtakunnansovittelija Paavolan toukokuussa 1975 tekemä sovintoesitys hylättiin, ja FOT sekä SRTVS aloittivat lakon 29.5.1975. RTTL osallistui lakon murtamiseen. Ajatuksellisesti vastaavaa oli käytetty vuosien 19481949 lakkoja murrettaessa neljännesvuosisata aiemmin. ${ }^{40}$ Lakko oli julistettu koskemaan töitä, joita freelancerit tekivät. Eli lakonalaista työtä tekevä oli rikkuri. Lakosta tuli pitkä. Se jatkui heinäkuun lopulle.

Lakon aikana SRTVS hajosi. Selostajajärjestön sisällä kulki jakolinja. Vasta työelämässä aloittaneet nuoret haastoivat Markus Similän kaltaiset ansioituneet "porvaritoimittajat" ja SDP:n puolueriidan oikeistosiiven järjestöpukarit. Lakon kahdeksantena päivänä, torstaina 5.6.1975, SRTVS:n jäsenkokoukseen saapui kuutisenkymmentä jäsentä. Kokouksen puheenjohtajaksi valittiin äänin 32-15 järjestöammattilainen Kauko-Aatos Leväaho. Vastaehdokas oli yhdistyksen puheenjohtaja Pertti Lampinen. Similän ja Leväahon tueksi tulleet jäsenet päättivät 32:1la äänellään, että yhdistys irrottautuisi lakosta perjantaiaamuna. Kaappaus onnistui. Raastupaa vilauteltiin. Käytännössä SRTVS:n parivuotinen työmarkkinataival päättyi tuohon kesäkuun iltaan. ${ }^{41}$

Sovittelija Paavolan parannettu välitysesitys valmistui heinäkuun puolivälissä. FOT:n 549 äänioikeutetusta freelancerista 291 (53\%) äänesti. Heistä hyväksymistä kannatti 145 $(49,8 \%)$ ja vastusti 143 (49,1\%). Tyhjiä ääniä oli kaksi ja hylättyjä yksi. Lakko päätyi 23.7.1975.
Lopettamissopimukseen liittyi muutamia ehtoja: joitakin määräyksiä alettiin noudattaa "soveltuvin osin myös freelance-kirjeenvaihtajiin ja -kuvanvaihtajiin”, jotka uusina ryhminä lisättiin sopimuksen soveltamisalaan. $\mathrm{Oy}$ Yleisradio Ab sitoutui "kohtelemaan työnseisaukseen osallistuneita radio- ja $\mathrm{Tv}$-freelancerohjelmatyöntekijöitä täysin tasavertaisesti muiden hakijoiden kanssa”. Tämä tuotti runsaasti päänvaivaa työnteettäjätaholle. Päättämissopimuksen allekirjoitti Yleisradion puolesta Kolamo. ${ }^{42}$

Lakon loppua edisti SAK. Tekerillä oli muitakin Yleisradion henkilökuntaa koskevia sopimuksia, jotka olivat lähiaikoina katkolla. Työnantaja ymmärsi, ettei ensimmäiseksi kannattanut allekirjoittaa sopimuksia lakkorintamasta livenneiden kanssa. Selostajien "liityntäsopimuksen” pykälään 24 tuli maininta, että ellei mahdollisessa riitatapauksessa sovintoa synny, niin "voidaan asia siirtää Suomen Työnantajain Yleisen Ryhmän ja Teknisten ja Erikoisammattien Liitto r.y:n neuvoteltavaksi. Liittojen välisissä neuvotteluissa on voimassa, mitä STK:n ja SAK:n välillä tehdyssä yleissopimuksessa on määrätty”. ${ }^{43}$

Lakko tuli, samoin sopimus, aikaa kului kahdeksan viikkoa. Matti Santajärvi muistelee RTTL:n historiassa episodia, joka tuntuu solidaarisuudessaan uskomattomalta:

Taisi olla 1975, kun FOT:n lakon lopettamisvaihe oli käsillä [...]. Ylen hallitus piti pääjohtaja Raatikaisen johdolla kokousta. Vein paperin [...], sanoin herroille: 'älkää sitten olko mitään

40 Vuoden 1948 ns. Leino-lakot sekä kesän 1949 lakkoliikehdintä, ks. Tapio Bergholm, Sopimusyhteiskunnan synty, vol. 1, Työehtosopimusten läpimurrosta yleislakkoon: SAK 1944-1956 (Keuruu: Otava, 2005), 210-218, 242-255.

41 Lampinen saattoi sovittelijan tiedoksi kokoustapahtumat. Käsiarkiston aineisto vuoden 1975 lakosta, Valtakunnansovittelijan toimisto

42 Kolamo kehotti lakkolaisia palaamaan Yleisradioon työnhakijaksi vuosikymmenen kuluttua. Yhtiössä oli jo 1970-luvun alussa ollut käytössä n. 80 nimen "musta lista", hall. ptk. 29.4.1970, FOT C:1, TA. Lakon jälkeen vuonna 1975 muun muassa Marina Sundström ja Leif Salmén olivat liipasimella. Tuki-ilmauksia muun muassa 2.10.1975 Finlands Svenska Skådespelarförbund (Leif Wager \& Martin Kurtén) ja 24.10.1975 Yleisradion Tekniset (Pekka Siren \& Jukka Pilli). FOT F:16, TA.

43 Yleisradion ja SRTVS:n sopimus 28.7.1975 (RTTL 2.5.1. YLE/MTV:n muiden järjestöjen tes-asiat). 
saatanan luistelijoita'. Ei kestänyt kuin pari sekuntia, kun Erkki Raatikainen tuli perässäni käytävään ja kysyi: 'Oletteko nyt tosissanne'. Vastasin kyllä, ja lopputulos oli se minkä RTTL halusi. ${ }^{44}$

Muistelossaan Matti Santajärvi sijoittaa ay-jyräyksensä freelancer-lakon loppuvaiheeseen.

Osaltaan FOT erotti RTTL:n tien valinneet kymmenkunta rikkurijäsentään elokuussa 1975.45

\section{Epilogi}

Vuoden 1975 lakko oli työntekijöiden voitto, mihin vaikutti se, että he saivat tukea Suomen Ammattiliittojen Keskusjärjestöltä. Keskusjärjestön tuella freelancereiden työmarkkina-ase- ma koheni sekä ansiotaso ja sosiaaliturva parani. Mutta tarvittiin vielä toinen lakko - kolme vuotta myöhemmin - ennen kuin Yleisradio vakinaisti 300 pitkäaikaista freelanceria.

Freelancereita alettiin määritellä 1980-luvulla yrittäjiksi, joille ei kuulu samanlainen sosiaaliturva kuin palkansaajille. Freelancereiden ammattiyhdistysten palkkiosuositukset kiellettiin kilpailua vääristävinä kilpailulain muutoksella. Muiden pätkä- ja pakkoyrittäjien tavoin freelancerit on kuitenkin hyväksytty ammattiyhdistysten jäseniksi. Sanan "solidaarisuus" he ovat kuulleet, kun heiltä on haettu tukea ja sympatiaa vakituisten työriitojen ja joukkoirtisanomisten yhteydessä. He ovat olleet 2000-luvulla halpatyövoiman, pakkoyrittäjyyden ja pätkätyökauden prototyyppejä.

44 Leppänen \& Munck, 1961-2011, 42. RTTL:n historiikin perusteella kahdeksan viikon lakko kesti vain viisi viikkoa.

45 FOT erotti kymmenkunta rikkurijäsentään, erottamispäätös ja kirjeet 15.8.1975. Lisäksi FOT:n rikkurilistoissa on parikymmentä muuta nimeä. Heistä jokunen toimi myöhemmin muun muassa RTTL:n luottamustehtävissä. Yksi jäi valitsematta Sosialistisen nuorisointernationaalin IUSY:n pääsihteeriksi vuonna 1979 rikkuruuden vuoksi. Osa teki huomattavan journalistiuran myöhemmin, FOT H:13, TA. 